\title{
Formación de taumasita en morteros hidráulicos mediante la deposición de $\mathrm{SO}_{2}$ atmosférico
}

\author{
Thaumasite formation in hydraulic mortars by \\ atmospheric $\mathrm{SO}_{2}$ deposition
}

M.T. BLANCO-VARELA,J.AGUILERA,S.MARTÍNEZ-RAMÍREZ,A.PALOMO (",C.SABBIONI,C.RIONTINO,G.ZAPPIA ("); K. VANVALEN, E.E.TOUMBAKARI ('")

\author{
(") Instituto de Ciencias de la Construcción Eduardo Torroja (CSIC), ESPAÑA \\ (") Institute ISAO, National Research Council, ITALIA \\ ('“) Dept. of Civil Engineering, KU Leuven, BELGICA
}

Fecha de recepción: 26-IX-2001

\begin{abstract}
RESUMEN
La sulfatación de morteros y hormigones depende de las condiciones ambientales ( $\mathrm{SO}_{2}$, aerosol, temperatura, etc.,), asi como de las características del material. Una de las fases que se puede formar como consecuencia de la sulfatación de los ligantes hidráulicos es la taumasita. En este trabajo se han expuesto diferentes morteros hidráulicos en cámaras de laboratorio con el fin de reproducir la formación de taumasita por efecto del $\mathrm{SO}_{2}$ atmosférico. Bajo las condiciones de laboratorio se formó taumasita en los morteros de cal hidráulica y en los morteros fabricados con cemento portland y cemento blanco mineralizado. Sin embargo, cuando el ligante utilizado en los morteros fue cal y puzolana, no se formó taumasita. El yeso fue el primer producto formado en la interacción entre los morteros y el $\mathrm{SO}_{2}$. A continuación, este yeso reaccionó con la calcita y el gel $C$-S-H dando lugar a la formación de taumasita. Las bajas temperaturas favorecieron la formación de taumasita.
\end{abstract}

\section{SUMMARY}

Sulphation of mortars and concretes is a function of diverse environmental factors ( $\mathrm{SO}_{2}$, aerosol, temperature, etc) as well as some material characteristics. One of the phases that could be formed as consequence of the sulphation of the hydraulic binder is thaumasite. In this paper different hydraulic mortars have been exposed to laboratory exposure chambers in order to reproduce thaumasite formation due to atmospheric $\mathrm{SO}_{2}$. Under the laboratory exposure conditions, thaumasite was formed in hydraulic lime mortars, and mortars elaborated with ordinary portland cement as well as mineralized white portland cement. However, thaumasite was not formed in mortars made of lime and pozzolan. The first product formed as a result of the $\mathrm{SO}_{2}$-mortar interaction was gypsum. Gypsum reacted with calcite and $C-S-H$ gel, present in the samples, giving place to thaumasite. Low temperature promotes thaumasite formation.

\section{INTRODUCCIÓN}

La sulfatación de morteros y hormigones es función de diversos factores entre los que cabe destacar las concentraciones de $\mathrm{SO}_{2}$ y aerosol en el aire, la temperatura, la humedad relativa, la velocidad del viento y la presencia de agua líquida, por lo que se refiere a condiciones ambientales; además también depende de las características del material, es decir de su composición química y mineralógica, porosidad, permeabilidad, etc. (1)

\section{INTRODUCTION}

The sulphation of mortars and concretes is a function of diverse environmental conditions; among those it is necessary to highlight $\mathrm{SO}_{2}$ and aerosol concentration in the air, temperature, relative humidity, speed of the wind and presence of liquid water. It also depends on the characteristics of the material, that is to say on their chemical and mineralogical composition, porosity, permeability etc. (I) 
La matriz de morteros y hormigones hidráulicos, ya sean de cemento portland, de cal hidráulica o de cal y puzolana está mayoritariamente constituida por silicatos y aluminatos cálcicos hidratados, así como por portlandita y/o en su caso $\mathrm{CaCO}_{3}$. Cada una de estas fases reaccionará de modo distinto en ambientes contaminados de $\mathrm{SO}_{2}$ y como consecuencia de ello se podrían formar diversos compuestos como: sulfito y sulfato cálcicos hidratados, singenita, etc. $(2,3)$.

Una de las fases que se podrían formar como consecuencia de la sulfatación de los conglomerantes hidráulicos es la taumasita. Naturalmente esta fase no se formará por interacción directa del $\mathrm{SO}_{2}$ con el material, ha de haber una serie de etapas intermedias (disolución y oxidación del $\mathrm{SO}_{2}$ en la disolución acuosa que rellena los poros del conglomerante, etc.). Como consecuencia de la reacción de los ácidos así producidos con las fases del conglomerante se podrían dar las condiciones de precipitación de la taumasita. Hasta el momento actual no se ha llevado a cabo ningún estudio relacionado con la formación de taumasita en el que la fuente de sulfato sea el $\mathrm{SO}_{2}$ atmosférico.

El objetivo principal de este trabajo es abordar dicho tema por lo que se programó una experimentación a fin de reproducir la formación de taumasita a través de la interacción del $\mathrm{SO}_{2}$ atmosférico con morteros hidráulicos, mediante ensayos de simulación llevados a cabo sobre muestras expuestas en cámaras de laboratorio.

\section{EXPERIMENTAL}

\section{Preparación del mortero}

Se elaboraron probetas del mortero para los ensayos de cámara de simulación utilizando arena y cuatro ligantes diferentes: cal hidráulica, cal y puzolana, cemento portland (bajo en aluminio) y cemento portland blanco mineralizado. El análisis químico se presenta en la Tabla 1.

Se prepararon entre 35 y 40 probetas de mortero de

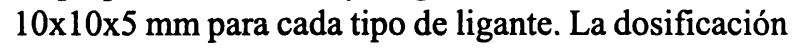
de los morteros fue la siguiente:

\footnotetext{
- Mortero MT1, elaborado con cal hidráulica y relación ligante/arena $=1 / 1$ y proporción agua/ligante $=0,6$
}

- Mortero MT2, fabricado con cal y puzolana con relación cal:puzolana:árido $=1: 1: 6$ y agua/cal + puzolana $=0,8$

- Mortero MT3, elaborado con cemento portland (OPC) y mortero MT4, elaborado con cemento portland blanco(BPC) mineralizado. Los morteros
The hydrated paste of hydraulic mortars and concretes, either of portland cement, of hydraulic lime or lime and pozzolan, it is mainly constituted by calcium silicate and calcium aluminate hydrates, as well as portlandite and/or $\mathrm{CaCO}_{3}$. Each one of these phases will react in a different way with atmospheric $\mathrm{SO}_{2}$ and consequently diverse compounds can be formed such as: calcium sulphite hydrate, gypsum, syngenite etc. $(2,3)$.

One of the phases that could be formed as a consequence of the sulphation of the hydraulic binder is thaumasite. Obviously this phase can not be formed by direct interaction between the $\mathrm{SO}_{2}$ and the material; a series of intermediate stages $\mathrm{SO}_{2}$ solution in water filling the pores of material, $\mathrm{SO}_{2}$ oxidation, $\mathrm{H}_{2} \mathrm{SO}_{3}$ and $\mathrm{H}_{2} \mathrm{SO}_{4}$ acids formation, etc.) should occur. As a consequence of the reaction among the previously mentioned acids and the binders, the conditions of precipitation of the thaumasite could be achieved. In the literature no data exist on the formation of thaumasite being the atmospheric $\mathrm{SO}_{2}$ the source of sulphation.

The main objective of this work is to fill such a gap in the knowledge and at this porpose an experimental work was carried out to reproduce the formation of thaumasite through atmospheric $\mathrm{SO}_{2}$-hydraulic mortars interaction, by mean of simulation tests carried out on mortars into a laboratory exposure chamber.

\section{EXPERIMENTAL}

\section{Mortar samples preparation}

Mortar specimens for the simulation chamber tests were elaborated using four different binders: hydraulic lime, lime and pozzolan, ordinary Portland cement (low in Al) and mineralized white portland cement, together with Sand. Chemical analyses are shown in Table 1.

35-40 mortar prisms of 10x10x5 mm for each type of binder were prepared. The dosage of mortars was prepared as follow:

- MT1 mortar, elaborated with hydraulic lime and binder $/$ sand ratio $=1 / 1$ and water/binder ratio $=0.6$

- MT2 mortar, elaborated with lime and pozzolan with lime: pozzolan: sand ratio $=1: 1: 6$ and water/ lime + pozzolan ratio $=0.8$

- MT3 mortar, elaborated with ordinary portland cement and MT4 mortar, elaborated with mineralized white portland cement. Mortars contained 20\% (wt) 
tienen $20 \%$ (peso) de $\mathrm{CaCO}_{3}$, con respecto a la cantidad de cemento. La relación ligante/árido $=1 / 3$ y la relación agua/ligante $=0,5$

Los procesos de curado de las muestras fueron diferentes dependiendo de la naturaleza del ligante.

Morteros de cal hidráulica (MT1): los moldes se mantuvieron durante un día a $21 \pm 1^{\circ} \mathrm{C}$ y $98 \%$ H.R. Posteriormente los prismas fueron desmoldados y se mantuvieron a $21 \pm 1^{\circ} \mathrm{C}$ y $100 \%$ HR durante 3 meses. A continuación, los prismas se carbonataron hasta que toda la portlandita se había transformado en $\mathrm{CaCO}_{3}$. Ambos procesos, hidratación y carbonatación fueron seguidos por difracción de rayos $\mathrm{X}$.

Morteros de cal y puzolana (MT2): los moldes se mantuvieron a $50^{\circ} \mathrm{C}$ y $100 \% \mathrm{HR}$ durante tres días. Las muestras fueron entonces desmoldadas y mantenidas a $50{ }^{\circ} \mathrm{C}$ y $100 \% \mathrm{HR}$ durante 4 días. Finalmente se sumergieron en agua a $50^{\circ} \mathrm{C}$ durante tres días más. A continuación las muestras se secaron en una estufa a $50^{\circ} \mathrm{C}$ durante tres horas.

Posteriormente se enfriaron y se llevaron a una cámara de carbonatación donde se mantuvieron aproximadamente 36 días en un ambiente de dióxido de carbono a $21^{\circ} \mathrm{C}$ y $50 \%$ HR. Los prismas se carbonataron hasta que toda la portlandita se había transformado en carbonato cálcico. El proceso de carbonatación fue seguido por difracción de rayos $\mathrm{X}$.

Morteros de cemento portland (MT3) y morteros de cemento portland blanco mineralizado (MT4): el molde se mantuvo a $21 \pm 1^{\circ} \mathrm{C}$ y $98 \%$ HR durante un día. Posteriormente, los prismas se desmoldaron y las muestras se sumergieron en agua durante aproximadamente 3 meses (hasta que la reacción se había completado). Finalmente, las probetas se carbonataron hasta que toda la portlandita se había transformado en $\mathrm{CaCO}_{3}$. Las reacciones fueron seguidas por difracción de rayos $\mathrm{X}$.

\section{Condiciones de exposición}

Con el fin de realizar los ensayos de exposición para simular la posible formación de taumasita, los morteros se sometieron a un ensayo de sulfatación acelerada exponiendo las muestras a $300 \mathrm{ppm} \mathrm{SO}_{2}$ a $25^{\circ} \mathrm{C}$ y $95 \%$ HR durante 2 dias. Seguidamente, la mitad de las muestras sulfatadas se expusieron durante 6 y 12 meses en cámara con $0,3 \mathrm{ppm}$ de $\mathrm{SO}_{2}$ con una velocidad de flujo de gas $0,50 \mathrm{I} \mathrm{min}-1$, a $5^{\circ} \mathrm{C}$ y $95 \% \mathrm{HR}$. La otra la mitad de las muestras sulfatadas aceleradamente se conservaron parcialmente sumergidas en agua a $5^{\circ} \mathrm{C}$ durante 4 y 9 meses. of $\mathrm{CaCO}_{3}$, with respect to the cement weight. Binder/ sand ratio $=1 / 3$ and water $/$ binder ratio $=0.5$

Different curing procedures were followed as a function of the binder nature.

Hydraulic lime mortars (MT1): the moulds were maintained at $21 \pm 1{ }^{\circ} \mathrm{C}$ and $98 \% \mathrm{RH}$ for one day. Then the prisms were demoulded and kept at $21 \pm 1$ ${ }^{\circ} \mathrm{C}$ and $100 \% \mathrm{RH}$ for 3 months. Then, prisms were carbonated until all portlandite was transformed into $\mathrm{CaCO}_{3}$. Both, hydration and carbonation processes were followed by $X$-ray diffraction.

Lime-pozzolan mortars (MT2): the moulds were maintained at $50{ }^{\circ} \mathrm{C}$ and $100 \% \mathrm{RH}$ for three days. The pieces were then demoulded and maintained at $50{ }^{\circ} \mathrm{C}$ and $100 \% \mathrm{RH}$ for 4 days. Finally they were immersed in water at $50^{\circ} \mathrm{C}$ for three extra days. After this, the specimens were dried in an oven at $50{ }^{\circ} \mathrm{C}$ for three hours. They were let to cool and then moved to a carbonation chamber where they remained for about 36 days in a carbon dioxide environment at $21^{\circ} \mathrm{C}$ and $50 \%$ RH. Prisms were carbonated until all portlandite was transformed into calcium carbonate. Carbonation process was followed by X-ray diffraction.

Ordinary portland cement mortars (MT3) and white portland cement mortars (MT4): the moulds were maintained at $21 \pm 1^{\circ} \mathrm{C}$ and $98 \% \mathrm{RH}$ for one day. Then the prisms were demoulded and immersed in water for about 3 months (time until total reaction). Finally prisms were carbonated until all portlandite was transformed into $\mathrm{CaCO}_{3}$. Reactions were followed by $X$-ray diffraction.

\section{Exposure conditions}

In order to perform exposure tests to simulate the possible formation of thaumasite, mortars underwent accelerated sulphation by exposing the samples to a $300 \mathrm{ppm} \mathrm{SO} \mathrm{S}_{2}$ atmosphere at $25^{\circ} \mathrm{C}$ and $95 \% \mathrm{RH}$ for 2 days. Subsequently, one half of the sulphated samples were exposed for 6 and 12 months in chamber with $0.3 \mathrm{ppm} \mathrm{SO}_{2}$ as pollutant with $0.50 \mathrm{l}$ min $^{-1}$ flow gas velocity, $5^{\circ} \mathrm{C}$ and $95 \%$ RH. The other half of the sulphated samples were conserved partially immersed in water at $5^{\circ} \mathrm{C}$ for 4 and 9 months. 
Para asegurar que las reacciones de sulfatación sólo ocurrirían en la superficie expuesta de las muestras, se aplicó un tratamiento de pasivación a las muestras por medio de una pintura de grafito en las 5 caras no expuestas, siendo la superficie expuesta de cada muestra de $1 \mathrm{~cm}^{2}$.

\section{Caracterización}

Después de 6 y 12 meses de exposición, las muestras se sacaron de las cámaras, se limpiaron quitando la pintura pasivante de grafito y se conservaron en una atmósfera inerte. Las muestras conservadas parcialmente sumergidas en agua a $5^{\circ} \mathrm{C}$ se sacaron a los cuatro y nueve meses. La caracterización de la porosidad, la composición química y mineralógica se llevaron a cabo por medio del porosímetro de intrusión de mercurio (MIP), cromatografía iónica (CI), espectroscopía infrarroja (FTIR) y microscopía electrónica (SEM-EDX) respectivamente.

\section{RESULTADOS}

La Tabla 1 muestra el análisis químico de las materias primas.

\section{Caracterización de los morteros}

\section{A.- Porosidad}

La evolución de la porosidad total de las muestras después de la exposición en cámara con 0,3 ppm de $\mathrm{SO}_{2}$ durante 6 y 12 meses se muestra en la Tabla 2 .

\section{B. - Determinación del sulfato y sulfito soluble}

En las muestras sometidas a la sulfatación intensiva durante 2 días se analizaron los iones sulfatos y sulfitos por medio de cromatografia iónica (CI). El análisis se muestra en la Tabla 3.

\section{C. - Caracterización microestructural \\ C. 1 MT1. - Morteros de cal hidráulica \\ a.- Sin tratamiento.}

A través de los análisis llevados a cabo por FTIR se puede concluir que las fases principales en esta muestra eran: cuarzo, carbonato cálcico y gel C-S-H. Debe destacarse la ausencia de las bandas correspondientes a las frecuencias de vibración de los grupos $\mathrm{SO}_{4}^{2-}$.
In order to ensure that the sulphation reactions would occur only on the exposed surface of the samples, a passivation treatment was applied to the samples by means of a graphite paint on the 5 nonexposed faces of the prisms. It left an exposed surface of $1 \mathrm{~cm}^{2}$ each sample.

\section{Characterisation}

After exposure for 6 and 12 months, the specimens were removed from the chambers, cleaned by removing the passivating graphite paint and preserved in an inert atmosphere. Samples conserved partially immersed in water at $5{ }^{\circ} \mathrm{C}$ were respectively removed after four and nine months. The porosity together with the chemical and mineralogical analyses were subsequently carried out by means of mercury intrusion porosimeter (MIP), ion chromatography (IC), infrared spectroscopy (FTIR) and electron microscopy (SEMEDAX).

\section{RESULTS}

Table 1 shows the chemical analysis of raw materials.

\section{Characterisation of mortars}

\section{A.-Porosity}

The evolution of the total porosity of the specimens after exposure in chamber with $0.3 \mathrm{ppm}$ of $\mathrm{SO}_{2}$ for 6 and 12 months is shown in Table 2.

\section{B.- Soluble sulphate and sulphite}

Sulphate and sulphite ions were measured by means of ion cromatography (IC) in samples submitted to intensive sulphation for 2 days. The data are reported in Table 3.

\section{C.- Microstructural characterisation \\ C. 1 MT1.-Hydraulic lime mortars \\ a.- Without treatment in chamber.}

Through analyses carried out by FTIR it was concluded that the main phases in this sample were: quartz, calcium carbonate and $C-S-H$ gel. It is worth pointing out the absence of the bands corresponding to the characteristic vibrations of $\mathrm{SO}_{4}^{2-}$ group. 
TABLA $1 /$ TABLE 1

Análisis químico de las materias primas / (Chemical analysis of raw materials)

\begin{tabular}{|c|c|c|c|c|c|c|}
\hline & $\begin{array}{c}\text { OPC } \\
\text { (\%peso) } \\
\text { (\%wt) }\end{array}$ & $\begin{array}{c}\text { BPC } \\
\text { (\%peso) } \\
\text { (\%wt) }\end{array}$ & $\begin{array}{c}\text { CAL } \\
\text { HIDRAÚLICA } \\
\text { (\%peso) } \\
\text { HYDRAULIC } \\
\text { LIME(\%wt) }\end{array}$ & $\begin{array}{c}\text { PUZOLANA } \\
\text { (\%peso) } \\
\text { POZZOLAN } \\
\text { (\%wt) }\end{array}$ & $\begin{array}{c}\text { CAL } \\
\text { (\%peso) } \\
L I M E \\
(\% w t)\end{array}$ & $\begin{array}{c}\text { ARENA } \\
\text { (\%peso) } \\
\text { SAND } \\
\text { (\%wt) }\end{array}$ \\
\hline P.F. & 1.66 & 0.80 & 22.66 & & 24.45 & 0.05 \\
\hline RI. & 0.57 & & $0.17^{*}$ & & 0.02 & 0.40 \\
\hline $\mathrm{SiO}_{2}$ & 20.44 & 24.34 & $21.22^{*}$ & 51.65 & 0.39 & 98.92 \\
\hline $\mathrm{Al}_{2} \mathrm{O}_{3}$ & 3.07 & 1.98 & 6.32 & 16.23 & 1.10 & 0.18 \\
\hline $\mathrm{Fe}_{2} \mathrm{O}_{3}$ & 4.08 & 0.37 & 1.80 & 7.55 & 0.20 & 0.06 \\
\hline $\mathrm{CaO}$ & 66.43 & 67.60 & 45.20 & 8.87 & 73.82 & 0.00 \\
\hline $\mathrm{MgO}$ & 0.94 & 0.55 & 1.34 & 4.21 & 0.0 & 0.28 \\
\hline $\mathrm{SO}_{3}$ & 2.90 & 2.78 & 0.98 & 1.45 & & \\
\hline $\mathrm{Na}_{2} \mathrm{O}$ & & 0.10 & - & 5.54 & & \\
\hline $\mathrm{K}_{2} \mathrm{O}$ & & 0.10 & & & & \\
\hline $\mathrm{SiO}_{2}$ so. & & & $9.66^{* *}$ & & & \\
\hline $\mathbb{R}$ & & & $17.13^{* *}$ & & & \\
\hline
\end{tabular}

(*) Ataque por fusión alcalina / Alkaline fusion attack

(**) Ataque por clorhidrico en frio / Cold acidic attack

TABLA $3 /$ TABLE 3

TABLA $2 /$ TABLE 2

Porosidad total de los morteros

(Total porosity of mortars)

\begin{tabular}{|lllll|}
\hline $\begin{array}{l}\text { Tiempo } \\
\text { exposición } \\
\text { Exposure time }\end{array}$ & $\begin{array}{l}\mathrm{MT} 1 \\
\left(\mathrm{~cm}^{3} / \mathrm{g}\right)\end{array}$ & $\begin{array}{l}\mathrm{MT} 2 \\
\left(\mathrm{~cm}^{3} / \mathrm{g}\right)\end{array}$ & $\begin{array}{l}\mathrm{MT} 3 \\
\left(\mathrm{~cm}^{3} / \mathrm{g}\right)\end{array}$ & $\begin{array}{l}\mathrm{MT} 4 \\
\left(\mathrm{~cm}^{3} / \mathrm{g}\right)\end{array}$ \\
\hline $\begin{array}{l}\text { Sin exponer } \\
\text { Non exposed } \\
6 \text { meses } \\
6 \text { months }\end{array}$ & 0,142 & 0,134 & 0,069 & 0,066 \\
12 meses & 0,128 & 0,117 & 0,076 & 0,074 \\
12 months & 0,154 & 0.145 & 0,074 & 0,067 \\
\hline
\end{tabular}

El análisis por SEM/EDX permitió observar en la superficie de la muestra, diferentes morfologías del gel $\mathrm{C}-\mathrm{S}-\mathrm{H}$, con composición química diferente. Puede verse también en la superficie la presencia de cristales de calcita (Figura 1), hecho que se haya en concordancia con los resultados de FTIR.

\section{b.- Sometido a un ambiente de $\mathrm{SO}_{2}$.}

El análisis a través de FTIR mostró una fijación progresiva de azufre, razón por la que aparecen las bandas de vibración características del grupo $\mathrm{SO}_{4}{ }_{4}^{2-}$. Las frecuencias a las que estas bandas aparecen coinciden con las del yeso $v_{4}\left(603\right.$ y $\left.^{2} 66 \mathrm{~cm}^{-1}\right)$ y $v_{3}(1.120$ y 1.144 $\mathrm{cm}^{-1}$ ). En los espectros de las muestras expuestas durante 6 meses, puede observarse una disminución de la intensidad de las bandas de calcita. Las probetas expuestas 12 meses muestran un nuevo aumento en la intensidad de las bandas del grupo carbonato.
Análisis por $\mathrm{CI}$ de los sulfatos y sulfitos presentes en los morteros después de la sulfatación acelerada $(300 \mathrm{ppm}$ $\mathrm{SO}_{2}, 25^{\circ} \mathrm{C}$ y $95 \% \mathrm{HR}$ durante 2 días)

(Ion Chromatography (IC) analyses of sulphates and sulphites in mortar after accelerated sulphation by exposing the samples to $300 \mathrm{ppm} \mathrm{SO}, 25^{\circ} \mathrm{C}$ and $95 \%$ $R H$ for 2 days)

\begin{tabular}{|lllll|}
\hline IONES & MT1 & MT2 & MT3 & MT4 \\
IONS & & & & \\
\hline $\mathrm{SO}_{3}{ }^{2}(\mathrm{mg} / \mathrm{g})$ & 3,817 & 3,182 & 1,891 & 1,565 \\
$\mathrm{SO}_{4}{ }^{=}(\mathrm{mg} / \mathrm{g})$ & 5,972 & 7,48 & 7,974 & 7,871 \\
\hline
\end{tabular}

SEM/EDAX analysis allowed to see on the surface of the sample different morphologies of C-S-H gel, with variable chemical composition. Moreover, in accordance with FTIR results, the presence of calcite crystals can be seen on the surface (Figure 1).

\section{b.- Submitted to a $\mathrm{SO}_{2}$ environment.}

The analysis through FTIR disclosed a progressive fixation of $S$, reason why vibration bands of the $\mathrm{SO}_{4}^{2-}$ group appear. The frequencies at which these bands appear coincide with those of gypsum: $v_{4}(603$ and $\left.669 \mathrm{~cm}^{-1}\right)$ and $v_{3}\left(1.120\right.$ and $\left.1.144 \mathrm{~cm}^{-1}\right)$. In these spectra, a decrease of the intensity of calcite bands can be observed in those samples exposed until 6 months. The sample exposed for 12 months shows a new increase in the intensity of the bands of carbonate. 
El análisis por SEM/EDX de la superficie de la muestra refleja señales claras del ataque después de 2 días de sulfatación intensiva. Esto es más evidente después de . 6 meses de tratamiento. El principal producto generado por este ataque es yeso. Una gran cantidad de cristales de yeso puede observarse en la superficie de la muestra (Figura 1b). La cantidad de yeso aumenta con el tiempo de la exposición hasta los 6 meses (Figura 1). Al mismo tiempo la calcita disminuye gradualmente.

Después de 12 meses de exposición, se produce un cambio micro-estructural importante en la superficie de la muestra, mientras que no se observan cristales de yeso, se observaron cristales de carbonato de calcio pobremente cristalizados en la superficie de la muestra (Figura 2).

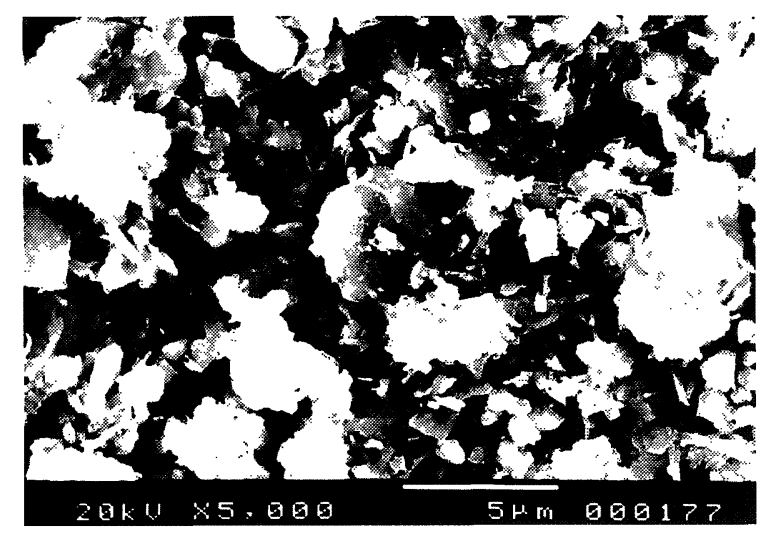

a
$S E M / E D A X$ analyses of the surface of the sample reflect clear signs of attack after 2 days of intensive sulphation. This is more evident after 6 months of treatment. The main product generated by this attack is gypsum. A large amount of gypsum crystals can be observed on the surface of the sample as shown in Figure $1 b$. The gypsum amount augments with exposure time until 6 months (Figure 1). At the same time calcite fade away gradually.

After 12 months of exposure, again an important micro-structural change is produced on the surface of the specimen: while gypsum crystals are not observed, poorly crystallised calcium carbonate crystals were observed on the surface of the sample (Figure 2).

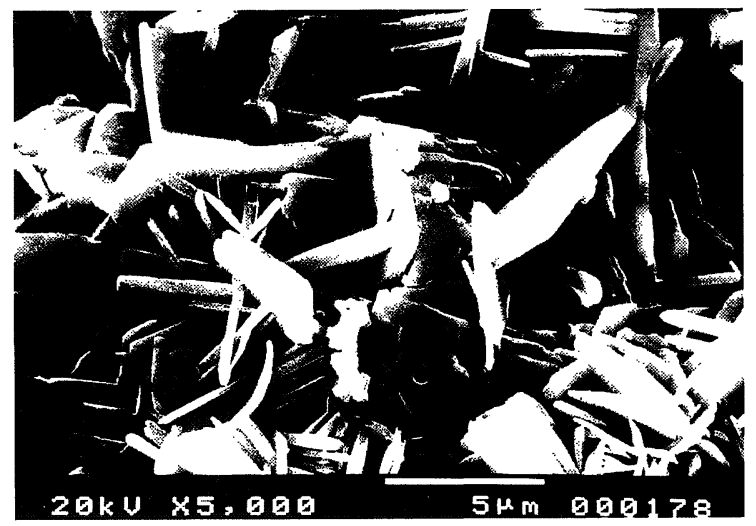

b

Figura 1.- Mortero MT1; a) antes de la exposición: presencia de cristales de calcita en la superficie; b) expuestos 6 meses: capa de yeso formada en la superficie de la muestra.

Figure 1.- MTI mortar; a) before exposure: presence of calcite crystals on the surface; b) 6 months exposure: gypsum layer formed on the sample surface.

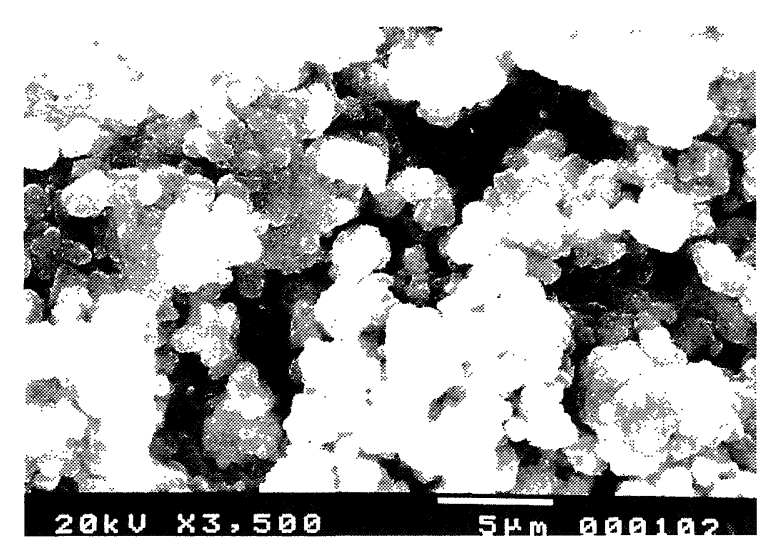

Figura 2.- Mortero MT1 expuesto 12 meses. Cristales de calcita pobremente cristalizados depositados en la superficie.

Figure 2.- MT1 mortar 12 months exposed. Poorly crystallised calcite crystals on the surface. 
La superficie de la muestra que se había mantenido parcialmente sumergida en agua durante 4 meses a la temperatura de $5^{\circ} \mathrm{C}$, presentaba algunos cristales de yeso y algunos otros cristales con forma de agujas que podrían identificarse como etringita o taumasita 0 incluso como una disolución sólida de ambas fases (Figura 3). Las muestras sumergidas en agua durante 9 meses a $5^{\circ} \mathrm{C}$, no presentaban cristales ni de yeso, ni de calcita. No se vieron las agujas previamente descritas.

\section{2 MT2. - Morteros de cal y puzolana}

\section{a.- Sin tratamiento.}

A través de FTIR se pudieron observar las bandas que pertenecen a cuarzo, calcita y gel C-S-H. Debe señalarse la ausencia de las bandas en las frecuencias de vibración del grupo $\mathrm{SO}_{4}{ }^{2-}$.

El estudio de la superficie de la muestra por medio de la técnica de SEM/EDX revela la existencia de diferentes morfologías del gel C-S-H en la muestra, con composición química variable y conteniendo algo de aluminio (Figura 4). Adicionalmente, se observa la presencia de cristales de calcita en la superficie lo que confirma los resultados de FTIR.

\section{b.- Sometido a ambiente de $\mathrm{SO}_{2}$.}

El análisis a través de FTIR, revela la presencia de azufre en las muestras expuestas durante 2 dias y 6
The surface of the sample, which was partially maintained immersed in water for 4 months at a temperature of $5^{\circ} \mathrm{C}$, presented some gypsum crystals and some other needles shaped crystals, which might be identified as ettringite or thaumasite or even like a solid solution of both phases (Figure 3). This sample immersed in water for 9 months at $5^{\circ} \mathrm{C}$, did not either present gypsum crystals, or calcite. The previously described needles were not seen.

\section{2 MT2.- Lime and pozzolan mortars \\ a.- Without treatment in chamber}

Through FTIR, bands belonging to quartz, calcite and $C-S-H$ gel are detected. The absence of bands of the $\mathrm{SO}_{4}{ }^{2-}$ group should be pointed out.

The study of the sample surface by means of SEMEDAX technique reveals the existence of different morphologies of the $C-S-H$ gel in the specimen, having variable chemical composition and containing some Al, (Figure 4). Additionally, the presence of calcite crystals on the surface becomes visible and confirms FTIR results.

\section{b.- Submitted to $\mathrm{SO}_{2}$ environment.}

The analysis through FTIR, reveals the presence of $S$ in specimens exposed 2 days and 6 months to the $\mathrm{SO}_{2}$
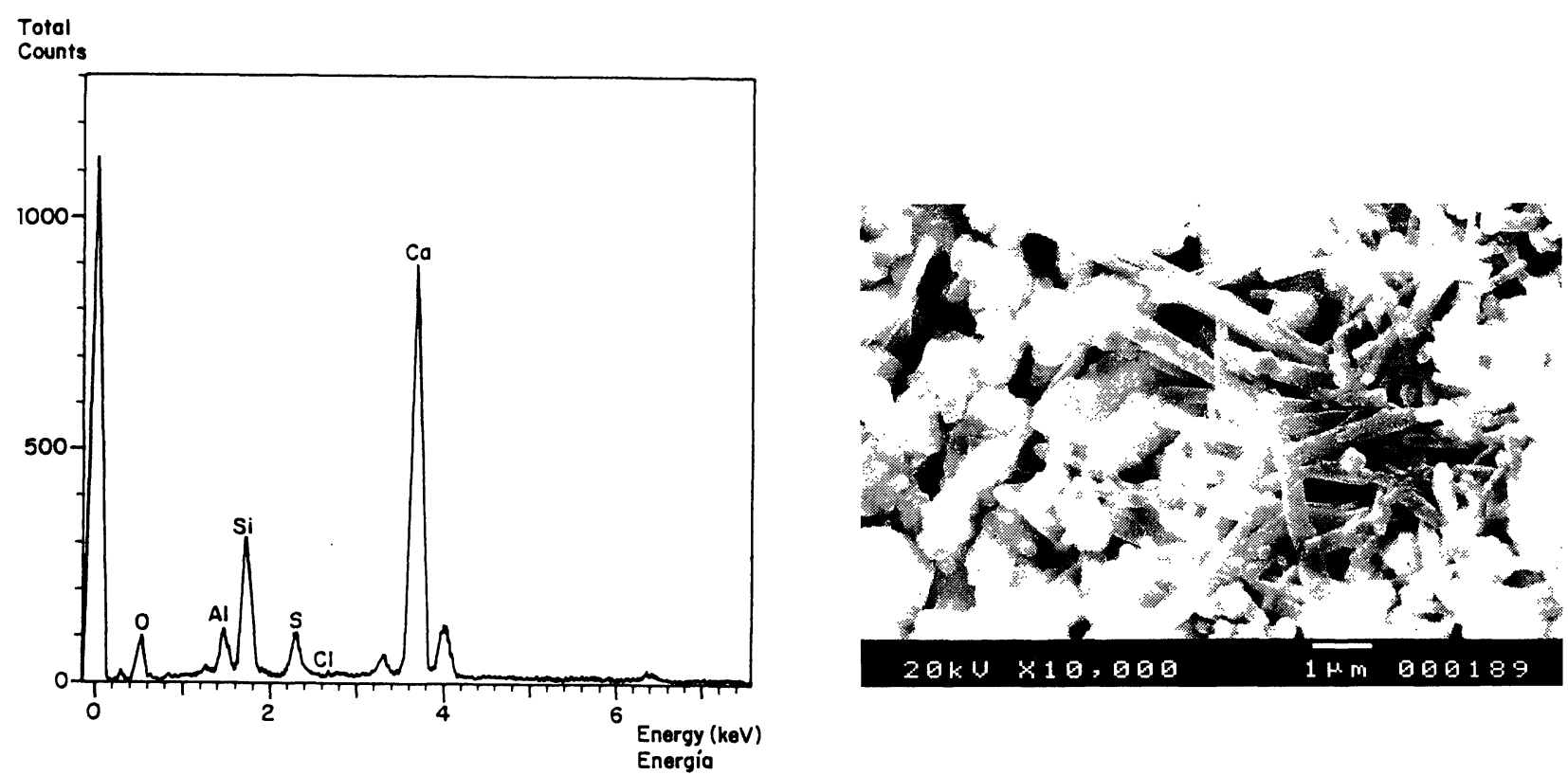

Figura 3.- Mortero MT1, 4 meses mantenido a $5^{\circ} \mathrm{C}$. Microfotografia y análisis EDX de las agujas identificadas como taumasita o disolución sólida etringitataumasita.

Figure 3.- MTI mortar, 4 months maintain at a $5{ }^{\circ} \mathrm{C}$. Micrograph and EDAX analysis of needles identified as thaumasite or thaumasite-ettringite solid solution. 

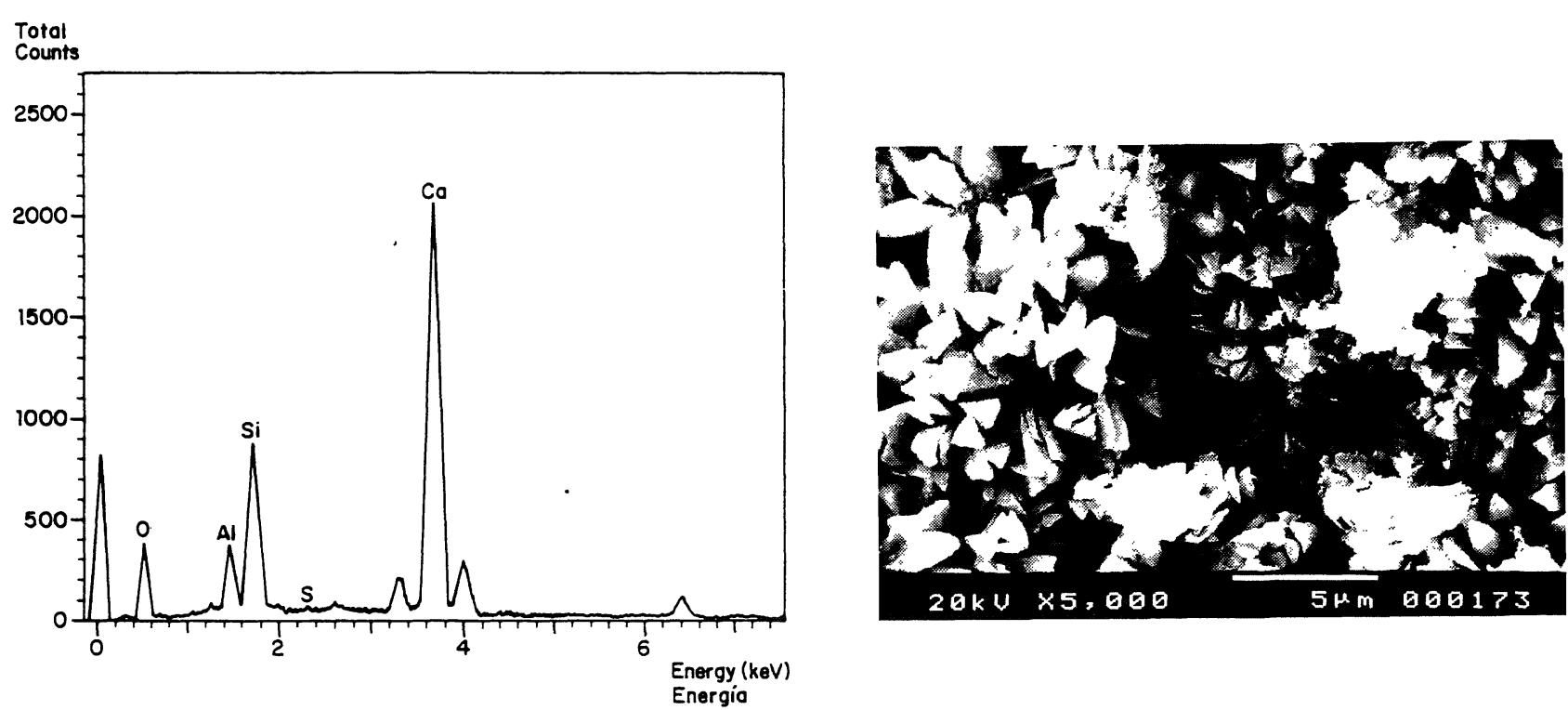

Figura 4.- Mortero MT2 antes de la sulfatación: EDX y micrografia del gel C-S-H y de los cristales de calcita depositados en la superficie.

Figure 4.- MT2 mortar before sulphation: EDAX and micrograph of C-S-H-gel and calcite crystals on the surface.

meses al ambiente de $\mathrm{SO}_{2}$. En los espectros aparecen las bandas de vibración debidas al grupo $\mathrm{SO}_{4}{ }^{2-}$. Considerado las frecuencias a las que estas bandas aparecen, $v_{4}\left(602,643,657 \mathrm{~cm}^{-1}\right), v_{1}\left(979,1.000 \mathrm{~cm}^{-1}\right)$ y $v_{3}\left(1.104,1.139\right.$ y $\left.1.191 \mathrm{~cm}^{-1}\right)$, podría considerarse que la sal formada es singenita. Adicionalmente, debido al efecto del $\mathrm{SO}_{2}$, se observa una disminución de la intensidad de las bandas de calcita. Esta clara disminución desde los 2 días a los 6 meses de exposición es debida a la descomposición de la calcita por ataque de los ácidos producidos en la sulfatación.

A través de microscopía electrónica se observa un cambio en la morfología de la superficie de la muestra. Las distintas señales del ataque se hacen más fuertes con el paso de tiempo de tratamiento desde 2 días hasta 6 meses. Los diferentes análisis llevados a cabo mostraron la progresiva fijación de azufre (más elevado a los 6 meses), así como mayores cantidades de potasio, posiblemente provenientes de la leucita presente en la puzolana empleada. El azufre parece que se fija como singenita $\mathrm{CaK}_{2}\left(\mathrm{SO}_{4}\right)_{2} \cdot \mathrm{H}_{2} \mathrm{O}$, ya que los cristales aparecen en toda la superficie; los análisis y la morfología están de acuerdo con ello (Figura 5), confirmando los resultados de FTIR. Después de 12 meses de exposición en la cámara de simulación, se produce un cambio microestructural importante en la superficie de las muestras; no se observan cristales de singenita (Figura 5).

La muestra MT2 parcialmente sumergida en agua durante 4 meses a $5^{\circ} \mathrm{C}$ mostró la presencia de singenita y cristales de yeso en su superficie. La environment. Some bands due to $\mathrm{SO}_{4}{ }^{2-}$ vibration appear in the spectra. Considering the frequencies at which these bands appear, $v_{4}\left(602,643,657 \mathrm{~cm}^{-1}\right), v_{1}$ $\left(979,1.000 \mathrm{~cm}^{-1}\right)$ and $v_{3}(1.104,1.139$ and 1.191 $\left.\mathrm{cm}^{-1}\right)$, they could be regarded as syngenite. Additionally, because of the $\mathrm{SO}_{2}$ effect, a decrease of the intensity of the calcite bands is observed. This clearly visible decrease from 2 days to 6 months of exposure is due to the transformation of calcite by $\mathrm{SO}_{2}$ attack.

By means of the electron microscope a change in the morphology of the specimen surface is observed. Distinct signs of attack become stronger as treatment runs from 2 days to 6 months. The different analyses carried out show the progressive deposition of $\mathrm{SO}_{2}$ (higher at 6 months), as well as the high amounts of the potassium, possibly coming from the leucite present in the employed pozzolan. Sulphur dioxide gives rise to the formation of syngenite $\mathrm{CaK}_{2}\left(\mathrm{SO}_{4}\right)_{2} \cdot \mathrm{H}_{2} \mathrm{O}$, since crystals appear through the whole surface; analyses and morphology are in accordance with it (Figure 5) confirming the FTIR results. After 12 months of exposure in the simulation chamber, an important microstructural change is again produced on the surface of the specimen; syngenite crystals are not seen (Figure 5).

MT2 sample maintained partially immersed in water for 4 months at $5{ }^{\circ} \mathrm{C}$ showed syngenite and gypsum crystals on the surface. MT2 sample conserved 9 


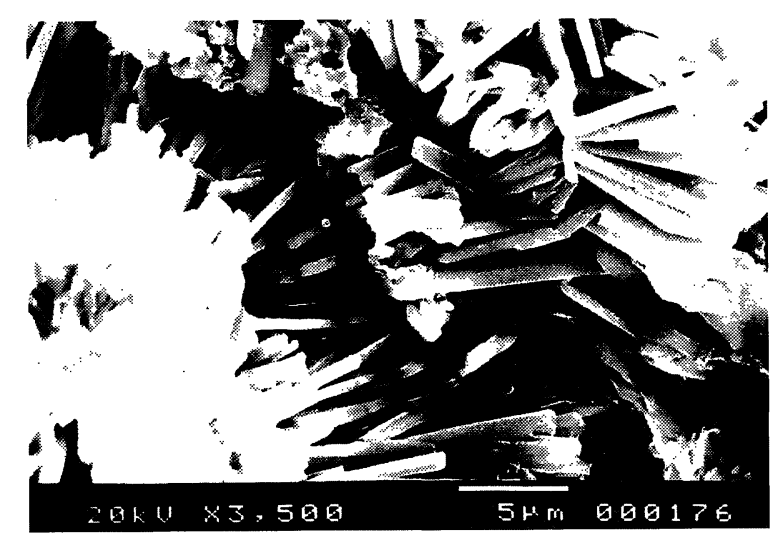

a

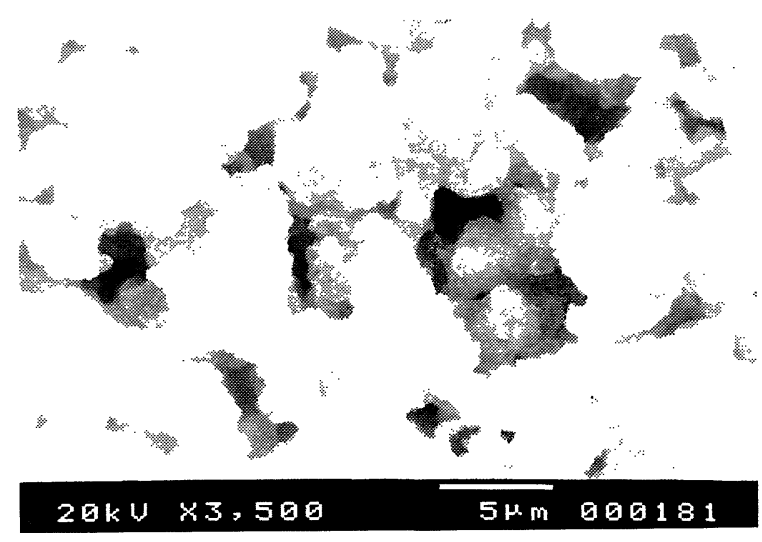

b

Figura 5.- Mortero MT2; a) expuesto 6 meses: cristales de singenita en la superficie de la muestra; b) expuestos 12 meses: microfotografia SEM de la superficie.

Figure 5 .- MT2 mortar; a) 6 months exposed: syngenite crystals in the surface of the sample; b) 12 months exposed: SEM micrograph of the surface.

muestra MT2 conservada 9 meses en las mismas condiciones reveló algunos cambios microestructurales. La muestra no tenía singenita; $\sin$ embargo, podría identificarse en la superficie la presencia de yeso y calcita.

\section{3 MT3. - Morteros de cemento portland con bajo contenido de $\mathrm{Al}_{2} \mathrm{O}_{3}$}

a.- Sin tratamiento

A través de FTIR, se pueden ver las bandas características del grupo carbonato de la calcita y la vibración de las uniones Si-O de gel C-S-H y del cuarzo. El estudio de la superficie de la muestra mediante la técnica de SEM/EDX, confirma los resultados anteriores: la existencia de diferentes morfologías del gel C-S-H, con composición química variable y relación $\mathrm{C} / \mathrm{S}>2$. En la muestra aparecen abundantes cristales de calcita procedentes de la carbonatación superficial del $\mathrm{Ca}(\mathrm{OH})_{2}$.

b.- Sometido a ambiente de $\mathrm{SO}_{2}$

Los resultados del análisis FTIR muestran que los morteros han sido alterados por dos procesos simultáneos: la progresiva fijación/estabilización de azufre, y la descomposición de la calcita. En los espectros de las muestras expuestas 2 días aparecen nuevas bandas del grupo sulfato que son debidas a la estabilización de azufre. La intensidad de estas bandas aumenta con el tiempo de exposición. También puede verse una disminución de la intensidad de las bandas debidas a la calcita, descomposición producida por el ataque del $\mathrm{SO}_{2}$. months in the same conditions revealed some microstructural changes. The sample did not contain syngenite; however, some gypsum and calcite could be identified on the surface.

\section{3 MT3.- Low $\mathrm{Al}_{2} \mathrm{O}_{3}$ ordinary portland cement mortars}

\section{a.- Without treatment in chamber}

Through FTIR, the characteristic bands of carbonate group due to calcite, and $\mathrm{Si}-\mathrm{O}$ vibration bands from the $C-S-H$ gel and quartz are seen. The study of the surface of the sample with SEM/EDAX, confirms previous results: existence of different morphologies of $C-S-H$ gels, with variable chemical compositions and ratio $C / S>2$. In the whole specimen abundant calcite crystals appear as a result of a carbonation process of the superficial $\mathrm{Ca}(\mathrm{OH})_{2}$.

b.- Submitted to $\mathrm{SO}_{2}$ ambient

Results from FTIR analyses show that two simultaneous processes have altered mortars: progressive fixation/stabilisation of sulphur, and decomposition of calcite. In the spectra new $\mathrm{SO}_{4}$ bands, which are due to the stabilisation of sulphur, appear in specimens with 2 days exposure. The intensity of those bands increases with time of exposure. It can be also seen a decrease of the intensity of the bands due to calcite, which bear decomposition due to $\mathrm{SO}_{2}$ attack. 
El estudio de la superficie de la muestra por medio de la técnica de SEM/EDX confirma los datos de FTIR: el aumento de azufre a través de toda la muestra (gel C-S-H y áridos) y la eliminación progresiva de la calcita en la superficie de la muestra. A los 6 meses, no se observa calcita. Después de 12 meses, puede observarse en la superficie de la muestra una capa de un sulfato de calcio, no muy bien cristalizada (prọbablemente yeso).

La muestra sumergida parcialmente en agua durante 4 meses a la temperatura de $5^{\circ} \mathrm{C}$, presentaba en la superficie algunos cristales de calcita y gel C-S-H. Adicionalmente, en la superficie de la muestra pueden observarse cristales de yeso junto con algunas agujas que podrían ser de taumasita (Figura 6). Después de 9 meses, pueden verse muchos cristales de taumasita en la superficie de MT3 (Figura 7).

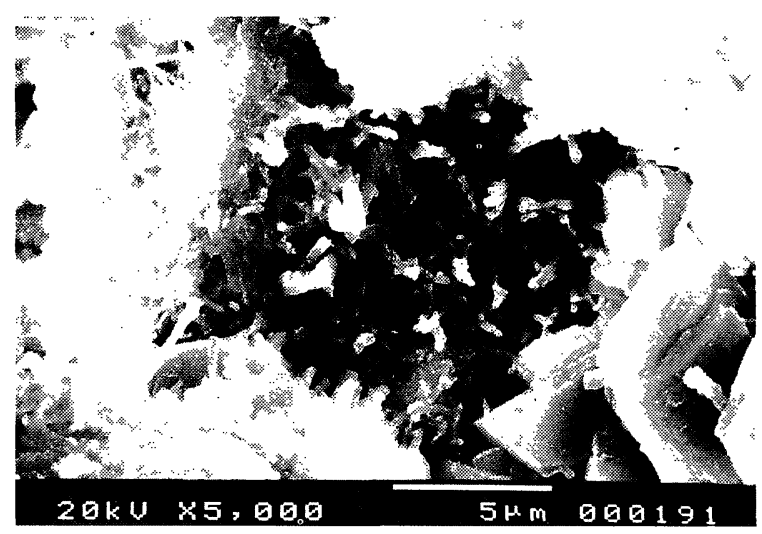

The study of the sample surface by means of SEMEDAX confirms FTIR data: the increase of sulphur through the whole specimen, (C-S-H gel and aggregates) and the progressive elimination of the calcite on the surface of the sample. At 6 months, no calcite is observed. After 12 months, a layer of a not very well crystallised calcium sulphate (probably gypsum), can be observed on the sample surface.

The sample maintained partially immersed in water for 4 months at a temperature of $5^{\circ} \mathrm{C}$, had some calcite crystals and $C-S-H$ gel on the surface. Additionally, gypsum crystals together with some needles, which could be thaumasite, can be observed on the surface of the sample (Figure 6). After 9 months, a lot of thaumasite crystals can be seen on the MT3 surface (Figure 7).

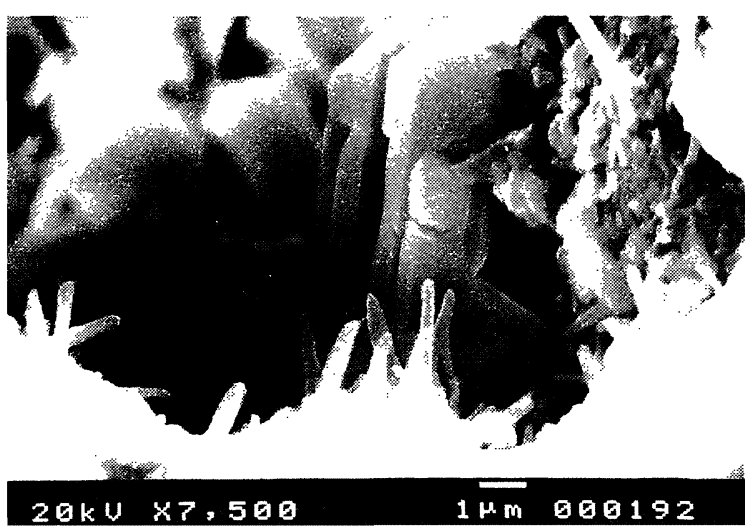

Figura 6.- Mortero MT3 después de 4 meses de conservación. Pequeños cristales de taumasita.

Figure 6.- MT3 mortar after 4 months of conservation. Small crystals of thaumasite.
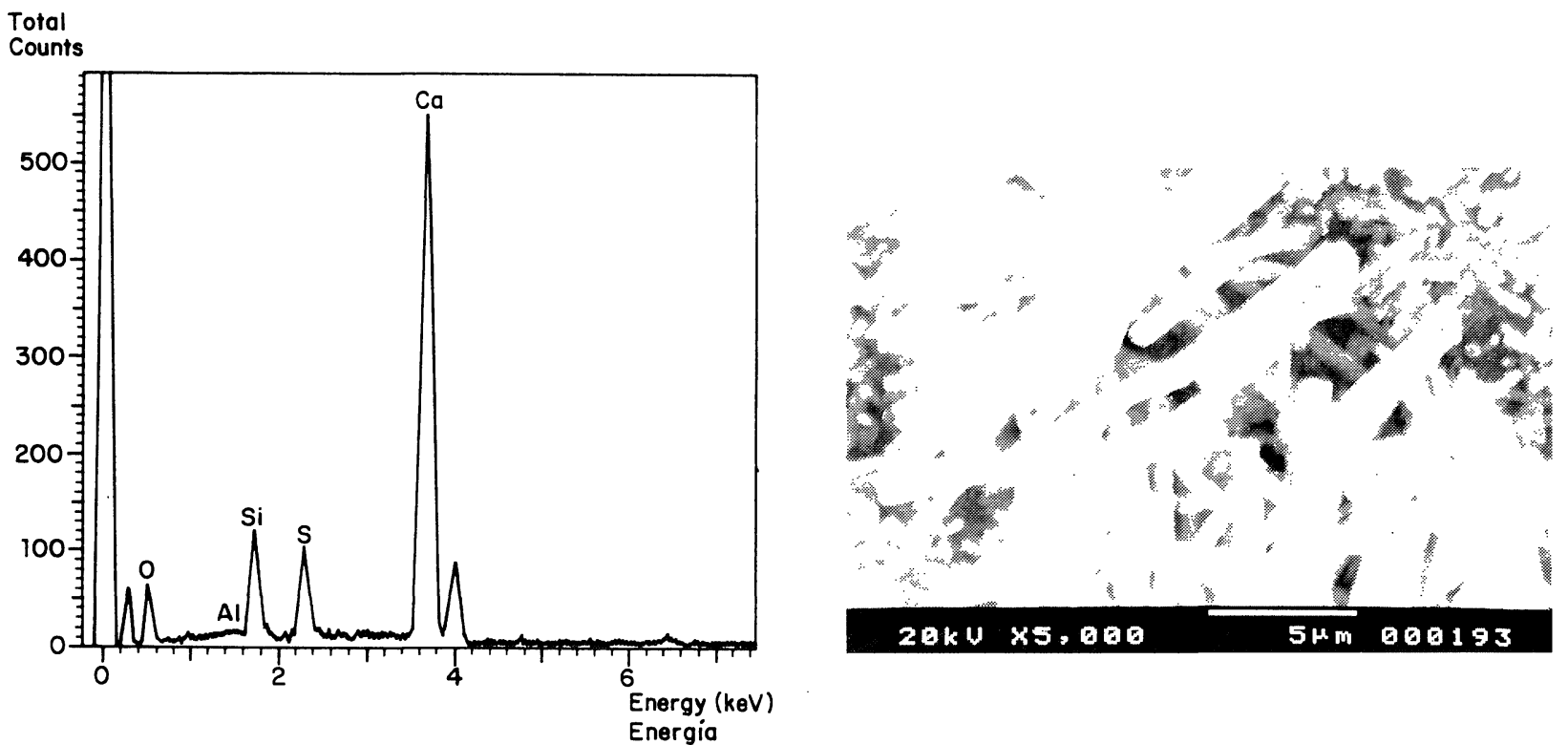

Figura 7. Mortero MT3 después de 9 meses de tratamiento. Cristales bien desarrollados de taumasita con su registro de EDX.

Figure 7. MT3 mortar after 9 months of treatment. Well developed crystals of thaumasite and EDAX pattern. 


\section{4 MT4. - Morteros con cemento portland blanco mineralizado}

a.- Sin tratamiento en cámara

El espectro FTIR muestra las bandas características de absorción debidas al cuarzo, la calcita y el gel C-S-H. Estudiando la superficie de la muestra con el microscopio electrónico, se han observado diferentes morfologías del gel C-S-H con composiciones químicas variables y elevada proporción de la relación $\mathrm{C} / \mathrm{S}$. También se observan en la muestra abundantes cristales de calcita procedentes de la carbonatación superficial.

b.- Sometido a atmósfera de $\mathrm{SO}_{2}$

Los resultados de FTIR descubrieron los dos procesos de ataque en los morteros: la fijación de azufre y la descomposición de la calcita. Aparecen nuevas bandas debidas al grupo $\mathrm{SO}_{4}{ }^{2-}$ procedente de la fijación de azufre en las muestras después de 2 días de exposición. La intensidad de estas bandas aumenta con el tiempo de exposición. También se observa una disminución de intensidad de las bandas vibración de los grupos $\mathrm{CO}_{3}{ }^{2-}$ de la calcita; lo que sugiere un proceso de descomposición debido al ataque de $\mathrm{SO}_{2}$.

El estudio de la superficie de la muestra por medio de la técnica de SEM/EDX confirma, al igual que antes, un ataque progresivo de $\mathrm{S}$ en la muestra. El azufre aparece en las diferentes morfologías del gel $\mathrm{C}-\mathrm{S}-\mathrm{H}$, con un aumento notable a los 6 meses de exposición. Además, el ataque podría causar la descomposición de los cristales de calcita de la superficie ya que la cantidad de este compuesto disminuye después de 2 días de sulfatación intensiva. Después de 6 meses de exposición no se observa calcita.

Adicionalmente, después de 2 días de exposición, aparecen en la muestra un grupo de agujas (máxima longitud $10 \mu \mathrm{m}$ y máximo espesor $0,25 \mu \mathrm{m}$ ). Las mismas agujas aparecen después de 6 meses de exposición, pero más grandes y más abundantes. La forma y composición (Figura 8) sugiere que estos cristales pueden atribuirse a taumasita, aunque contienen $\mathrm{SO}_{4}^{2-}$ en exceso.

Finalmente, la superficie de la muestra mantenida parcialmente sumergida en agua durante 4 meses a la temperatura de $5^{\circ} \mathrm{C}$, mostró algunos cristales de calcita y un gel C-S-H muy rico en azufre. Pueden observarse en la superficie de la muestra algunos cristales de yeso y algunas agujas que podrían ser de taumasita (Figura 9). Después de 9 meses de tratamiento en la cámara, el tamaño de las agujas ha aumentado y la presencia de taumasita o de disolución sólida taumasita-etringita en las muestras es clara (Figura 10).

\section{4 MT4.- Mineralised white portland cement mortars}

\section{a.- Without treatment in chamber}

FTIR spectra shows the characteristic absorption bands due to calcite, quartz and $C-S-H$ gel. By studying the surface of the sample with the electron microscope, different morphologies of $C-S-H$ gel, with variable chemical compositions and high $C / S$ ratio have been observed. Also abundant calcite crystals from superficial carbonation are present in the sample.

\section{b.- Submitted to $\mathrm{SO}_{2}$ atmosphere}

FTIR results disclosed the two processes of mortars weathering: fixation of $S$ and decomposition of calcite. $\mathrm{New}$ bands due to $\mathrm{SO}_{4}{ }^{2-}$ from sulphur fixation in specimens with 2 days exposure appear. The intensity of those bands increases with time of exposure. A decrease of intensity of the $\mathrm{CO}_{3}$ bands from calcite is also observed; it suggests a decomposition process due to the $\mathrm{SO}_{2}$ attack.

The study of the sample surface by means SEM-EDAX confirms the same as before: a progressive attack from the environmental sulphur is observed on the specimen. Sulphur appears on the different morphologies of the $C-S-H$ gel, with a remarkable increase at 6 months of exposure. Moreover, the attack could cause the decomposition of calcite crystals on the surface since the amount of this compound diminished after 2 days of intensive sulphation. After 6 months of exposure, no calcite can be seen.

Additionally, after 2 days of exposure, a group of needles (maximum $10 \mu \mathrm{m}$ length and $0.25 \mu \mathrm{m}$ thick) appears on the specimen. The same needles appear after 6 months of exposure, but larger and more abundant. The shape and composition (Figure 8) suggest that these crystals can be attributed to thaumasite, although they contain some $\mathrm{SO}_{4}{ }^{2-}$ in excess.

Finally, the surface of the sample maintained partially immersed in water for 4 months at temperature of $5^{\circ} \mathrm{C}$, showed some calcite crystals and a very rich in sulphur C-S-H gel. Some gypsum crystals and some needles, which could be thaumasite, can be observed on the surface of the sample, too (Figure 9). After 9 months of treatment into the chamber, the size of needles have increased and the presence of thaumasite or thaumasite-ettringite solid solution in samples remain clearly (Figure 10). 

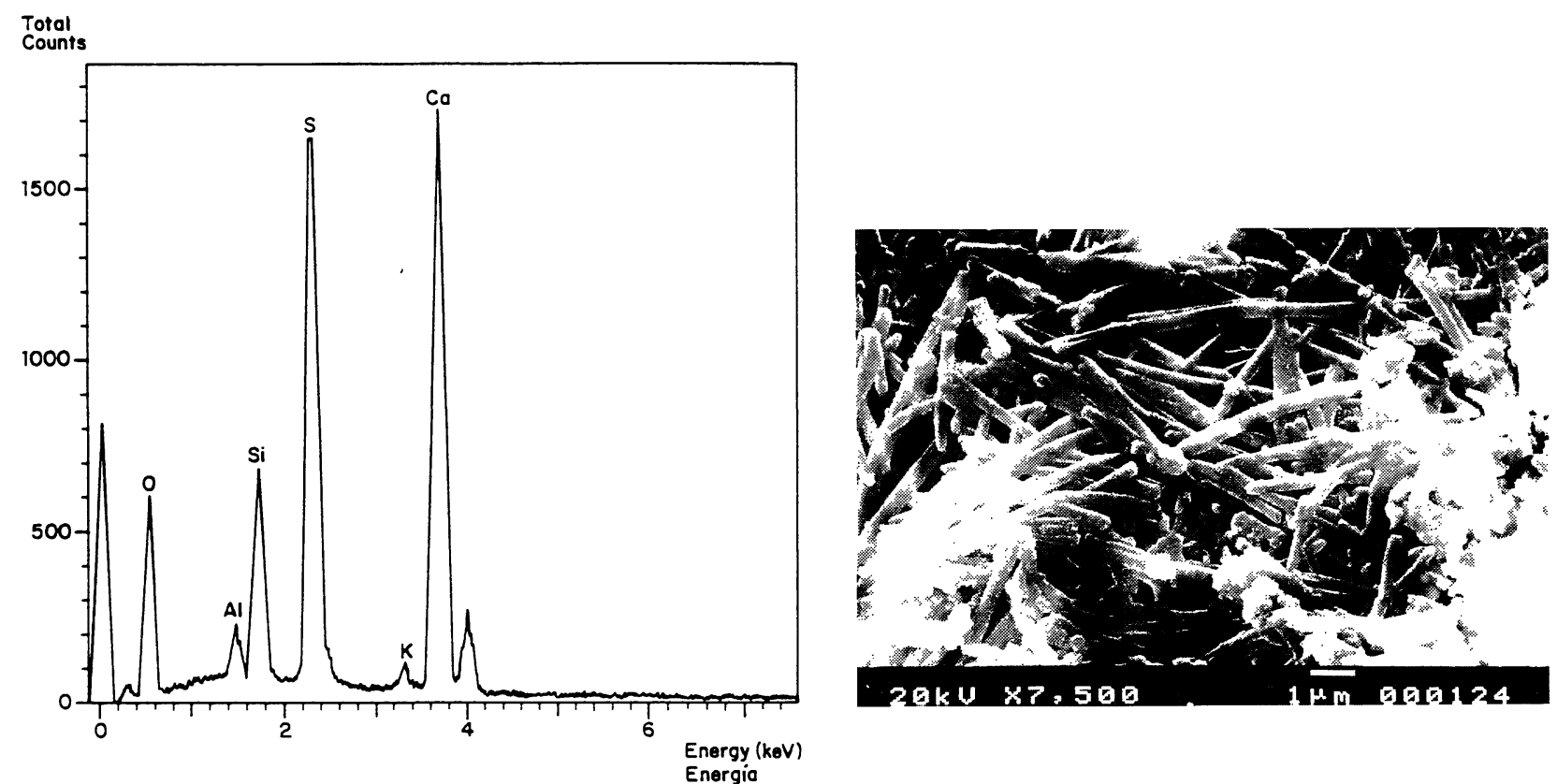

Figura 8.- Mortero MT4, 6 meses en la cámara. EDX y microfotografia de los cristales con forma de aguja; probablemente taumasita y yeso.

Figure 8.- MT4 sample, 6 months in chamber. EDAX and microphotography of the needle shaped crystals; likely thaumasite and gypsum. Total
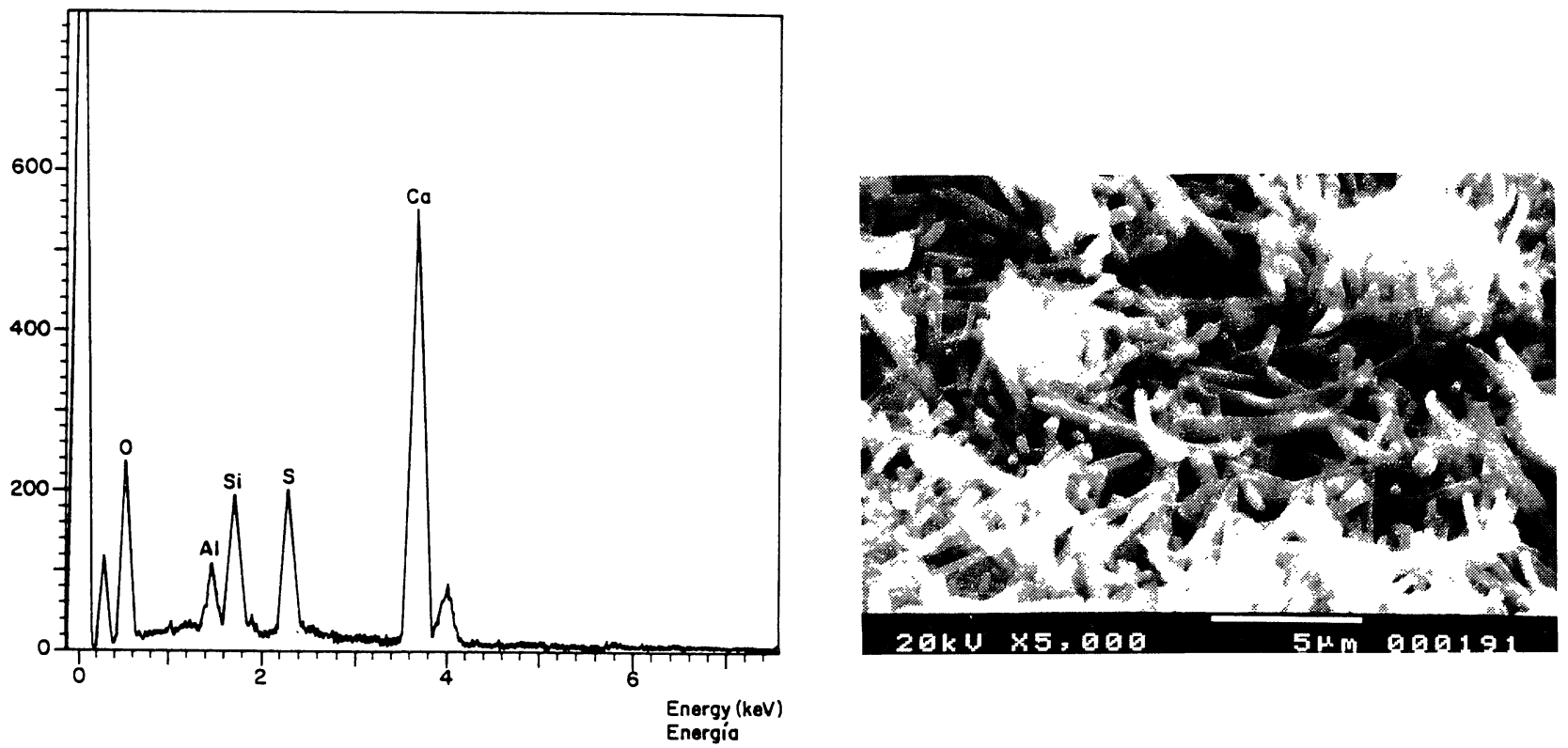

Figura 9.- Mortero MT4 después de 4 meses de tratamiento. EDX y microfotografia de cristales de taumasita o disolución sólida taumasita-etringita.

Figure 9.- MT4 after 4 months of treatment. EDAX and microphotography of thaumasite crystals or thaumasite-ettringite solid solution crystals.

\section{DISCUSIÓN}

Los análisis de cromatografia iónica de las muestras sometidas a una sulfatación acelerada $(300$ ppm y 2 días) revelan que todas ellas contienen sulfitos y sulfatos solubles y que los cuatro morteros reaccionaron intensamente con el gas contaminante. A

\section{DISCUSSION}

The analyses through ionic chromatography of those samples subjected to an accelerated sulphation (300 ppm and 2 days) reveals that all of them contain soluble in water sulphite and sulphate and that the four mortars reacted intensely with the polluting gas. 


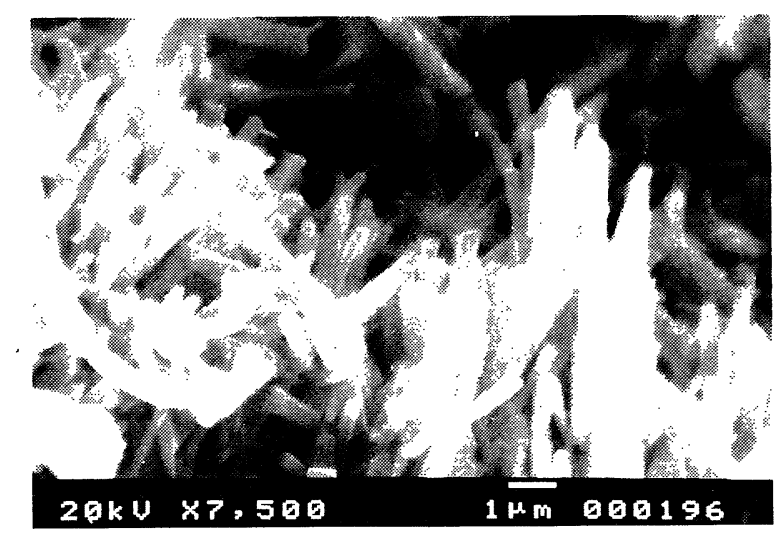

Figura 10.- Mortero MT4 después de 9 meses de tratamiento. EDX y microfotografía de los cristales de taumasita o de la disolución sólida taumasita-etringita.

Figure 10. - MT4 after 9 months of treatment. EDX and microphotography of thaumasite crystals or thaumasite-etringite solid solution crystals.

pesar del corto período de tiempo de esta primera exposición la cantidad de azufre incorporado en las muestras es elevado, del mismo orden o superior al azufre fijado por los morteros de cemento y cal y puzolana después de 90 días de ensayo en la cámara de exposición, conteniendo 3 ppm de $\mathrm{SO}_{2}$ en el aire (3).

La presencia de sulfito indica que debido a la acción del $\mathrm{SO}_{2}$ de la atmósfera, el proceso de sulfatación ocurre a través de un mecanismo de interacción heterogénea con las siguientes etapas $(4,5,6)$ : a) disolución del $\mathrm{SO}_{2}$ en el agua, lo que da lugar a la formación de iones sulfito y protones; b) oxidación del ion sulfito a ion sulfato. Así pues, el ion sulfito es un producto intermedio en el mecanismo de sulfatación, que ocurre por interacción gaseosa del $\mathrm{SO}_{2}$, el cual, después de la hidratación, se oxida a S(VI) en la superficie del material.

De acuerdo con la bibliografia, a igualdad de otras condiciones, la sulfatación de los morteros depende fundamentalmente de su naturaleza y de la porosidad, siendo aquélla mayor cuanto mas poroso es el material y siendo el orden de reactividad $(3,7)$ :

Mortero de cal y puzolana $<$ Mortero de cal $<$ Mortero de cemento

Los morteros MT1 y MT2, los mas porosos, son también los que experimentan mayor sulfatación, superior a la experimentada por los morteros de cemento MT3 y MT4. En este caso, la naturaleza del ligante influye menos ya que durante el proceso de carbonatación se sustituyó la portlandita de los morteros de cemento por calcita, con lo que su composición mineralógica y el pH de la disolución que
In spite of the short period of time of this first exposure the amount of $S$ incorporated by the samples is high, similar or even higher than the sulphur fixed by the cement and lime and pozzolan mortars after 90 days exposed into the environmental simulating chamber containing $3 \mathrm{ppm}$ of $\mathrm{SO}_{2}$ in the air (3).

The sulphite ion presence indicates that due to the action of the atmospheric $\mathrm{SO}_{2}$, the sulphation process occurs through a mechanism of heterogeneous interaction with the following stages $(4,5,6):$ a) $\mathrm{SO}_{2}$ dissolution in water, giving place to the formation of sulphite ions and protons; b) oxidation of the ion sulphite into ion sulphate. Therefore the ion sulphite is an intermediate product in the sulphation mechanism of the dry deposition of $\mathrm{SO}_{2}$. After the hydration, sulphite ion oxidised into sulphate over the surface of the material.

According to bibliography, the sulphation of the mortars mainly depends on the nature and on the porosity of the material. The higher the porosity, the higher the sulphation process is. The reactivity of materials is as follows $(3,7)$ :

Lime and pozzolan mortar < Lime mortar < cement mortar

Both MT1 and MT2 mortars, with the highest porosity, are also those resulting with highest sulphation; higher than that of cement mortars MT3 and MT4. In this last case the nature of the binder has less influence since during the carbonation process the portlandite of the cement mortars is replaced by calcite. Furthermore the mineralogical composition and the $\mathrm{pH}$ of the porous solution for cement mortars turn similar to those of the 
rellena su red porosa se hace más similar a los de los morteros de cal hidráulica o de cal y puzolana. La cantidad de azufre fijado en las muestras así tratadas depende entonces menos del conglomerante usado en su elaboración que de otros factores como son la porosidad, superficie específica, etc.

A su vez, el proceso de sulfatación difiere de alguna manera en ambos tipos de morteros ya que los de cemento fijan mayoritariamente el azufre en forma de sulfatos, en tanto que los morteros MT1 y MT2 lo fijan fundamentalmente en forma de sulfitos. Ello quiere decir que el proceso de oxidación se produce más rápidamente en los morteros de cemento (9).

La caracterización mineralógica y microestructural de los morteros tras los 6 y 12 meses en la cámara de simulación revela dos procesos comunes a todos ellos: la fijación progresiva del azufre sobre las distintas morfologías presentes en las muestras, y la desaparición de los cristales de calcita de su superficie.

Los cristales de calcita de la superficie se descomponen por el ataque ácido del proceso de sulfatación. El azufre fijado en las muestras está en general en forma de yeso (MT3 y MT4 a los 6 y 12 meses; MT1 a los 6 meses; MT2 a los 12 meses). En el mortero MT2 se identificó singenita tras la sulfatación acelerada de las muestras que era aún más abundante a los 6 meses de ensayo; posteriormente, a los 12 meses, se observó la desaparición de los cristales de singenita y la formación de yeso. La singenita se forma a partir de los iones calcio liberados en la descomposición de la calcita o gel C-S-H y de los iones potasio liberados por la puzolana, que reaccionan con los iones sulfato. La singenita formada es metaestable y se descompone con el tiempo (10). Finalmente, en la muestra MT4, a los 12 meses de ensayo, se observan, a través de SEM/EDX, unas agujas en las que se identifican los elementos $\mathrm{Ca}, \mathrm{Si}, \mathrm{S}, \mathrm{y} \mathrm{Al}$. Podría tratarse de mezcla de cristales de yeso y etringita y /o taumasita, pero la identificación no ha sido concluyente.

Los ensayos de simulación de ambientes contaminados a los que han sido expuestos los morteros no producen modificaciones sustanciales en su porosidad total, que permanece similar a los 12 meses de ensayo (muestra MT4), o aumenta ligeramente (muestras MT1, MT2 y MT3).

La evolución de las muestras sometidas al proceso de sulfatación acelerada durante dos días en cámara con $300 \mathrm{ppm}$ de $\mathrm{SO}_{2} \mathrm{y}$, posteriormente, mantenidas en agua a $5^{\circ} \mathrm{C}$, durante 4 , y 9 meses fue muy diferente. Así en los dos morteros de cemento MT3 y MT4 se observa hydraulic lime or lime and pozzolan mortars. So, the amount of $S$ fixed in the samples studied in these conditions is lesser dependent on the type of binder used than on factors like porosity, specific surface, etc.

In turn the sulphation process differs for both types of mortars since those made of cement fix the sulphur mainly in form of sulphates, however, mortars MT1 and MT2 fix it fundamentally as sulphite. That means that the oxidation process takes place for the cement mortars faster than for the other studied mortars (9).

The mineralogical and micro-structural characterisation of the mortars after 6 and 12 months into the simulation chamber reveal the existence of two common processes: the progressive fixation of the $S$ on the different morphologies present in the samples, and the disappearance of the calcite crystals from the surface.

Calcite crystals over the surface break down due to acidic attack during the sulphation process. Generally speaking the sulphur fixed in the samples is in form of gypsum (MT3 and MT4 at 6 and 12 months; MT1 at 6 months; MT2 at 12 months). In mortar MT2 syngenite was identified after accelerated sulphation of the samples. Syngenite was found to be abundant after 6 months of exposure; but later, after 12 months, the disappearance of the syngenite crystals and the formation of gypsum was observed. Syngenite is formed from the calcium ions released in the decomposition of the calcite or $C-S-H$ gel and from the potassium ions released by the pozzolan. Both can then react with the sulphate ions present in the system. The formed syngenite is metaestable and breaks down with time (10). Finally in the sample MT4 after 12 months of exposure, some needles are observed through SEM/ EDAX. Elemental analyses of the needles reveals the existence of $\mathrm{Ca}, \mathrm{Si}, \mathrm{S}$ and Al. It could be a mixture of gypsum, ettringite and lor thaumasite, but the identification has not been conclusive yet.

The test of simulation of polluted atmospheres to which were submitted our materials, do not produce substantial modifications in total porosity of the mortars. This characteristic (porosity), remains similar after 12 months of exposure (sample MT4), or slightly increases (sample MT1, MT2 and MT3).

The evolution of the samples submitted to the process of accelerated sulphation in chamber for two days (300 ppm of $\mathrm{SO}_{2}$ ) and then maintained partially immersed in water at $5^{\circ} \mathrm{C}$, during 4 , and 9 months was very different: in the two cement mortars, MT3 and MT4 
claramente, después de 4 meses de inmersión, cristales aciculares cuya morfología y análisis sugiere que se trate de taumasita y de una disolución sólida o una mezcla de taumasita y etringita respectivamente. A los 9 meses, el número de dichos cristales en forma de aguja aumenta y se corrobora la identificación anteriormente realizada. El que en los morteros MT3 se identifique taumasita y en los MT4 mezcla o disolución sólida de taumasita y etringita se justifica por la composición mineralógica de los cementos. El primero de ellos exento de $\mathrm{C}_{3} \mathrm{~A}$ y el segundo con un cierto contenido de aluminato cálcico $(4 \%)$.

En ninguno de los dos morteros restantes, MT1 y MT2, se encontró taumasita a los 9 meses de ensayo. El mortero MT1 contiene taumasita y yeso a los 4 meses y en el mortero de cal y puzolana, MT2, se observó, a dicha edad, que su superficie estaba totalmente cubierta de agujas de singenita. En la muestra MT2 la singenita se había descompuesto a los 9 meses, encontrándose yeso y calcita en la superficie de la muestra, en tanto que en la muestra MT1 el yeso no fue observado.

La mayor facilidad de los morteros de cemento para formar taumasita respecto de los de cal hidráulica y cal y puzolana, se podría justificar por el mayor contenido de sulfatos de los primeros, ya que, además del debido a la sulfatación acelerada, poseen el del propio conglomerante.

Así pues, los ensayos de simulación en cámaras climáticas, con adición continua de $\mathrm{SO}_{2}$, realizados sobre morteros hidráulicos para tratar de reproducir la formación de taumasita, no han conseguido tal objetivo; tan sólo en la muestra MT4 se identificaron algunos cristales de forma acicular que podrían ser mezcla de yeso, etringita y/o taumasita. Se ha reproducido, sin embargo, el proceso de formación de taumasita en los morteros elaborados con cal hidráulica o con cementos con nulo o bajo contenido en aluminato cálcico, que han sido carbonatados, $y$ sometidos a sulfatación acelerada, cuando se mantienen sumergidos en agua a temperatura entre 1 y $5^{\circ} \mathrm{C}$, durante varios meses. En estas mismas condiciones no se detecta taumasita en los morteros de cal y puzolana ni a 4 ni a 9 meses de ensayo.

Las principales diferencias entre los dos tipos de ensayos radica en las condiciones de conservación: por una parte, las muestras sumergidas poseen una cantidad de agua importante que facilitaría los procesos de disolución y transporte de iones y, por consiguiente, la formación de taumasita; por otra parte, en los ensayos en la cámara, se mantiene la muestra expuesta a la acción del $\mathrm{SO}_{2}$, lo que incrementa su contenido en sulfatos, favoreciendo el proceso, pero genera una acidez continua en el medio, lo que podría dificultarlo. it was clearly observed, that after 4 months of immersion, acicular crystals were formed. The morphology and analysis of those crystals suggested that they were thaumasite in the case of MT3 mortar and a solid solution or a mixture of ettringite and thaumasite in the case of MT4 mortar. After 9 months of exposure, the number an size of these needle crystals increased and its identification was corroborated. This different results can be justified by the mineralogical composition of the cements; the first of them do not have $C_{3} A$ and the second one have $a$ certain content of calcium aluminate (4\%).

None of the two other mortars, MT1 and MT2, presented thaumasite after 9 months of testing. Mortar MT1 contained thaumasite and gypsum after 4 month of exposure. At this age, the surface of the lime and pozzolan mortar MT2, was completely covered with syngenite needles. In sample MT2 the syngenite was decomposed after 9 months, being gypsum and calcite the minerals on the surface of the sample. In sample MTI, gypsum was not observed after 9 months of test.

So, cement mortars have higher tendency to form thaumasite than hydraulic lime and lime and pozzolan mortars. It could be justified for the high content of sulphates of the former ones.

Therefore the simulation test in climatic chamber, with a continuous flow of $\mathrm{SO}_{2}$, carried out on hydraulic mortars trying to reproduce the environmental thaumasite formation have not reached such an objective; only in the sample MT4 some crystals with acicular shape were identified. Those crystals could be a mixture of gypsum, ettringite and/or thaumasite. However, the process of thaumasite formation has been reproduced in the mortars elaborated with hydraulic lime or with portland cements (without or with low calcium aluminate contents) submitted to the following processes: a) carbonation, b) accelerated sulphation and c) immersion in water at $1-5^{\circ} \mathrm{C}$, during several months. Under these same conditions thaumasite is not detected in lime and pozzolan mortars neither at 4 months of test nor at 9 months.

The main differences between the two types of tests arise from the conservation conditions: on one hand, the submerged samples possess a lot of water that would facilitate the process of dissolution and transport of ions and consequently the thaumasite formation; on the other hand, in the chamber test, the samples have been exposed to the a continuos $\mathrm{SO}_{2}$ action, increasing their sulphates content but generating a continuous acidity in the medium, what could avoid the process of formation of thaumasite. 
Por otra parte también estarían las probetas largo tiempo expuestas a la acción $\mathrm{CO}_{2}$, el cual podría descomponer la posible taumasita formada. Estos resultados estarían de acuerdo con algunos descritos en la bibliografia (8) en los que la taumasita se encuentra en la parte interna de los morteros, donde se mantienen condiciones de mayor humedad y no en la superficie en contacto con el $\mathrm{CO}_{2}$.

\section{CONCLUSIONES}

1. Se ha reproducido el proceso de formación de taumasita en morteros hidráulicos debido a la interacción del material con $\mathrm{SO}_{2}$, en muestras de cal hidráulica y cemento sometidas a un proceso de sulfatación acelerado y conservadas parcialmente sumergidas en agua, a $5^{\circ} \mathrm{C}$, durante varios meses. La taumasita no se formó en los morteros de de cal ypuzolana.

2. El yeso es el primer producto formado como resultado de esta interacción. Seguidamente, el yeso reacciona con el carbonato de calcio y el gel $\mathrm{C}-\mathrm{S}-\mathrm{H}$ dando lugar a la formación de taumasita.

3. Los ensayos de simulación en cámaras climáticas, con adición continua de $\mathrm{SO}_{2}$, realizados sobre morteros hidráulicos para tratar de reproducir la formación de taumasita, no han conseguido tal objetivo; si bien se forma inicialmente yeso, la formación de taumasita se ve dificultada y tan sólo en la muestra MT4 se identificaron algunos cristales de forma acicular que podrían ser mezcla de yeso, etringita y/o taumasita.

4. La formación de taumasita fue más fácil y más rápida en las muestras sulfatadas conservadas a temperatura baja parcialmente sumergidas en agua.

\section{AGRADECIMIENTOS}

Este estudio fue financiado por la CEE, dentro del programa Environment and Climate, por el Proyecto "Deterioro Medioambiental de Morteros Hidráulicos Antiguos y ModernosEDAMM" (Ct. n. ENV4-CT95-0096) y por el MCyT dentro del programa del PGC con el Proyecto PB98-0518. Los autores desean agradecer a la Dra. F. Puertas sus comentarios y sugerencias en la preparación de este trabajo. La Dra. S. Martínez-Ramírez desea agradecer al DGES (MEC) la concesión de un "Contrato de Incorporación de Doctores".
Additionally, mortars were exposed for a long period of time to $\mathrm{CO}_{2}$ action which could decompose the thaumasite formed. These results agree with some other data described in bibliography (8) where thaumasite was found in the internal part of the mortars where there exist a high humidity level and low concentration of $\mathrm{CO}_{2}$.

\section{CONCLUSIONS}

1. Thaumasite formation process in hydraulic mortars due to the interaction of the material with $\mathrm{SO}_{2}$, has been reproduced in the hydraulic lime and cement mortar samples, submitted to a accelerated sulphation process and conserved partially immerse in water at $5{ }^{\circ} \mathrm{C}$ for several months. Thaumasite was not formed in the lime pozzolan mortars (MT2).

2. Gypsum is the first product formed as a result of that interaction. Subsequently, gypsum reacts with calcium carbonate and $C-S-H$ gel giving place to thaumasite.

\section{The simulation tests carried out into the} weathering chambers (continuous flow of $\mathrm{SO}_{2}$ on hydraulic mortars) have not achieved the objective of reproducing the thaumasite formation. Gypsum is initially formed but no thaumasite; only in sample MT4 exposed for 12 months, some needle shaped crystals (they could be a mixture of gypsum, ettringite and/or thaumasite) were identified.

4. The formation of thaumasite was easier and quicker in sulphated samples conserved at low temperature and partially immersed in water.

\section{ACKNOWLEDGEMENTS}

This study was supported by the EC, within the programme Environment and Climate, Project "Environmental Deterioration of Ancient and Modern Hydraulic Mortars - EDAMM" (Ct. n. ENV4CT95-0096) and the MCyT within the PGC programme Project PB98-0518. Authors wish to thanks to Dr. F. Puertas for her comments and suggestions during the paper elaboration. Dra. S. Martinez-Ramirez wish to thank to DGES (MEC) for the "Contrato de Incorporación de Doctores" given to her. 


\section{BIBLIOGRAFÍA}

(1) Martínez-Ramírez, S.; Thompson. G.E. "Deterioro de morteros de cemento producido por la 'deposición' seca y húmeda de contaminantes atmosféricos". Materiales de Construcción. Vol. 48 (1998) № 250, pp.15-31.

(2) Martínez-Ramírez, S. "Influence of $\mathrm{SO}_{2}$ deposition on cement mortar hydration" Cement and Concrete Research (1999), 29 pp. $107-$ 111.

(3) Zappia, G.; Sabbioni, C.; Pauri, M.G. and Gobbi, G. "Mortar damage to airborne sulfur compounds in a simulation chamber". Materials and Structures. 27(1994), pp.469-473.

(4) C. Sabbioni, G. Zappia, C. Riontino, M.T. Blanco-Varela, J. Aguilera, F. Puertas, K. Van Balen, E.E. Toumbakari “Atmospheric deterioration of ancient and modern hydraulic mortars" Atmospheric Environment, 35 (2001), pp. 539-548.

(5)M.T. Blanco-Varela, J. Aguilera, F. Puertas, A. Palomo, C. Sabbioni, G. Zappia, C. Riontino, K. Van Balen, E.E. Toumbakari, O. Favoni (1999) "Enviromental effects of $\mathrm{SO}_{2}$ on hydraulic mortars". In: P.J.M. Bartos et al. (Eds.), Historic Mortars: Characteristics and Tests, Proceedings of RILEM Workshop, Paisley, Scotland, May. In press.

(6) Elfving P.; Panas I; Linqvist O."In situ IR study on the initial sulphition and carbonation of $\mathrm{Ca}(\mathrm{OH})_{2}$ and $\mathrm{CaO}$ by $\mathrm{SO}_{2}$ polluted air". Atmospheric Environment 30(23)(1996)pp. 4.085-4.089.

(7) Martínez-Ramírez, S.; Puertas, F.; Blanco-Varela, M" .T. and Thompson, G.E. "Studies on degradation of lime mortars in atmospheric simulation chambers". Cement and Concrete Research. 27 (1997), N 5. pp. 777-784

(8) N.J. Crammond “Thaumasite in failed cement mortars and renders from exposed brickwork” Cem. Conc. Res. 15 (1985), pp. 1.0391.050

(9) Elfving P.; Panas I; Linqvist O."Model study of the first step in the deterioration of calcareous stone. III. Manganese and iron mediated sulphation of natural stone". Applied surface science 78 (1994) pp. 373-384.

(10) Damidot D. And Glasser F.P. "Thermodynamic investigation of the $\mathrm{CaO}-\mathrm{Al}_{2} \mathrm{O}_{3}-\mathrm{CaSO}_{4}-\mathrm{K}_{2} \mathrm{O}-\mathrm{H}_{2} \mathrm{O}$ system at $25^{\circ} \mathrm{C}$ ". Cement and Concrete Research 23 (1993) pp. 1.195-1.204. 